\title{
KONTRIBUSI IMAM AL-GHAZALI TERHADAP EKSISTENSI TASAWUF
}

\author{
Asmaran As \\ UIN Antasari Banjarmasin \\ asmaranas@gmail.com
}

Diterima 19-03-2020 | Direview 02-06-2020 | Diterbitkan 27-06-2020

\begin{abstract}
In the first and second centuries of the Hijrah before the presence of Imam alGhazali, whose teachings of Sufism at that time were moral and practical, in the third and fourth centuries of Hijrah the teachings of Sufism developed towards philosophical understandings such as Ittihad and Hulul which are viewed by some scholars (theologians and fuqaha) have deviated from the teachings of Islam, as a result of which Sufism almost dies. In such a situation, in the fifth century $A H$, Imam al-Ghazali appeared to save him by trying to integrate between the teachings of Sufism with the teachings of figh and kalam, between fact and sharia, as can be seen in his book Ibya "Ulum al-Din (Reviving the Sciences Religion), so he is often referred to as Hujjatul Islam (Defender of Islam) because of his efforts to harmonize the teachings of Islam in a complete unity.
\end{abstract}

Keywords: Ittihad, Hulul, Integration Sufism with Sharia

\begin{abstract}
Abstrak
Pada abad pertama dan kedua Hijrah sebelum kehadiran Imam al-Ghazali, yang ajaran tasawuf saat itu bercorak ak.hlaki dan amali, pada abad ketiga dan keempat Hijrah ajaran tasawuf berkembang ke arah paham yang bercorak falsafi seperti paham Ittibad dan Hulul yang dipandang oleh sebagian ulama (teolog dan fuqaba) telah menyimpang dari ajaran Islam, yang akibatnya tasawuf hampir mengalami kematian. Dalam kondisi yang demikian, pada abad kelima Hijrah tampil Imam al-Ghazali menyelamatkannya dengan upaya mengintegrasikan antara ajaran tasawuf dengan ajaran fiqh dan kalam, antara bakikat dengan syariat, seperti yang dapat dilihat dalam kitabnya Ibya' 'Ulum al-Din (Menghidupkan Ilmu-Ilmu Agama), sebingga dia sering disebut sebagai Hujjatul Islam (Pembela Islam) karena usahanya mengharmonikan ajaranajaran Islam dalam sebuah kesatuan yang utuh.
\end{abstract}

Kata kunci: Ittihad, Hulul, Integrasi Hakikat dan Syariat 


\section{Pendahuluan}

Dalam rentang sejarah kehidupan dan perjuangan al-Ghazâlî (450-505 $\mathrm{H} / 1058-1111 \mathrm{M}$ ) yang panjang dan melelahkan untuk mencari pengetahuan yang benar yang hakiki, yang mampu meyakinkan dan memuaskan batinnya, akhirnya dia temukan pengetahuan yang benar itu setelah dia mendalami dan mengamalkan ajaran kaum sufi.

Sebelum al-Ghazâlî sampai kepada kesimpulan bahwa tasawuflah yang membawa kepada pengetahuan yang hakiki, yang membawanya menjadi seorang sufi, dia telah meneliti dengan seksama pengetahuan yang telah dia miliki dan segala macam pendapat, paham atau ajaran yang berkembang di zamannya; serta mengevaluasi diri, yaitu amal/ perbuatannya yang selama ini dikerjakannya. Apa yang dikerjakan oleh al-Ghazâlî ini menggambarkan proses perkembangan intelektual dan spiritual dalam sejarah kehidupannya untuk menemukan pengetahuan yang benar dan meyakinkan.

Al-Ghazâlî mempertanyakan pengetahuan yang selama ini dimilikinya yang merupakan hasil pengamatan dan penalarannya, tidak mau mengikuti begitu saja ajaran yang diwarisinya dari nenek moyangnya, dan tidak mudah terpengaruh oleh paham yang berkembang di zamannya. Tabiat dan sikap kritis ini diceritakan oleh al-Ghazâlî, telah ada sejak ia masih remaja hingga berumur 50 tahun, sebagaimana termaktub dalam kitabnya al-Munqidz min al-Dhalal

Jadi, sejak masa mudanya, al-Ghazâlî tidak mau menerima ajaran-ajaran yang semata-mata dilandasi oleh wewenang manusia kecuali disertai bukti-bukti yang kuat atau yang cukup beralasan. Bahkan, kemudian, dia tidak mau percaya kepada wewenang indera dan akalnya sendiri tanpa terlebih dahulu mengujinya secara ketat dan kritis, sesuai dengan fungsi dari keduanya sebagai instrumen pengetahuan. la mengatakan kepada kita, bahwa pada usia 20 tahun, ia telah membebaskan dirinya dari ikatan-ikatan taklid. Di dalam kitabnya al-Munqidz tersebut, al-Ghazâlî juga mengemukakan kesulitan-kesulitan yang dialaminya ketika ia berusaha mencari kebenaran dari kepercayaan yang bersimpang siur dari berbagai golongan ${ }^{2}$ Al-Ghazâlî merasa bahwa kesungguhannya untuk menemukan sendiri kebenaran tersebut lebih baik dibanding cara hidup yang taklid saja, karena dengan taklid orang tidak akan sampai pada tingkat pencapaian $^{3}$

\footnotetext{
${ }^{1}$ Al-Gazali AL-Ghazali, Al-Minqiz Min Al-Dalal (Turkey: Hakikat Kitabevi, 1981).

2 AL-Ghazali.

3 AL-Ghazali.
} 
Al-Ghazâlî membagi para pencari kebenaran pada masanya itu ke dalam empat kelompok ${ }^{4}$, yaitu :

1. Mutakallimin (para teolog), yaitu mereka yang menyatakan dirinya sebagai eksponen dari ahli pikir dan kaum intelektual.

2. Bâthiniyah, yaitu mereka yang mengaku sebagai kaum terpelajar dan secara khusus menerima pengetahuan dari Imâm yang ma'sum (orang yang terpelihara dari dosa).

3. Kaum filosof, yaitu mereka yang mengaku sebagai ahli logika dan ahli pembuktian.

4. Kaum sufi, yaitu mereka yang mengaku sebagai orang-orang pilihan yang telah sampai ke "hadirat" Tuhan, sebagai ahli musyâhadah dan mukâsyafah

Para teolog, penganut aliran Bâtiniyah dan para filosof mendapat kritik keras dari al-Ghazâlî, antara lain, lewat karyanya al-Munqidæ, Tahâfut dan Ibyâa. Dengan mengecualikan beberapa orang sufi, dia berkesimpulan bahwa para sufi itulah pencari kebenaran yang hakiki. Menurutnya, ilmu yang mereka capai bisa mematahkan hambatan-hambatan jiwa serta membersihkan moral atau sifatnya yang buruk dan tercela, sehingga mengantarkannya kepada keterbebasan kalbu dari segala sesuatu selain Allah serta menghiasinya dengan ingat kepadaNya. Lewat karya-karya para sufi dan ucapan-ucapan para tokohnya, al-Ghazâlî mulai mengkaji ilmu mereka, sehingga ia benar-benar mengetahui substansi tujuan keilmuan mereka serta berhasil mencapai apa yang bisa dia pelajari lewat cara mereka belajar ataupun mendengar dan mengamalkan ajaran mereka.

Meskipun ada hal-hal yang dikritik al-Ghazâlî dari pernyataan sebagian kaum sufi, namun hasil kajiannya terhadap ajaran-ajaran mereka sangat membekas ke dalam kalbunya. Dia segera meninjau arnal perbuatannya; dan ternyata, katanya, apa yang dia lakukan selama ini keliru, tidak karena Allah, tetapi karena kedudukan dan kemasyhuran.

\section{Metode}

Penelitian ini menggunakan jenis penelitian kualitatif dengan metode tematik. Metode ini sering dilakukan oleh beberapa peneliti karena metode ini sangat cocok untuk menguak dan menteulusi lebih dalam lagi suatu teori yang masih belum jelas atau teori tersebut masih dianggap belum dipahami oleh kalangan umum.

\footnotetext{
${ }^{4}$ AL-Ghazali, Al-Minqiz Min Al-Dalal.
} 


\section{Ajaran Tasawuf Bermasalah sebelum Imam al-Ghazali}

Sebagai pengamalan, tasawuf sebenarnya telah ada pada abad pertama dan kedua Hijrah atau padaawal sejaran Islam seperti yang dipraktekkan oleh Nabi saw dan para sahabat beliau seperti tekun beribadah, bersifat ikhlas, sabar, tawakal dan sifat-sifat terpuji lainnya. Ajaran seperti inilah yang diajarkan kaum sufí.

Berpegang teguh pada ajaran agama dan bersikap zuhud dalam kehidupan keseharian adalah suatu hal yang biasa bagi setiap muslim di masa permulaan Islam. Tidak ada kata yang lebih mulia selain kata sahabat, kemudian genarasi berikutnya yang disebut tabi'in. Tetapi ketika ada kecenderungan terhadap kehidupan duniawi yang berlebihan pada abad kedua Hijrah dan sesudahnya, maka dikatakan terhadap mereka yang kuat berpegang dan tekun menjalankan ajaran agama dengan perkataan zâhid dan âbid; dan akhirnya lahirlah perkataan tasawuf atau sufi. Pada mulanya kata sufi sesuai artinya dengan zâbid dan âbid. Kata-kata ini menunjukkan kometmen dan perhatian yang tinggi terhadap pengmalan ajaran Islam. Inilah kata Abû al-Wafâ' alTaftâzânî yang terjadi pada awal sejarah cikal bakal lahirnya ilmu tasawuf dalam Islam $^{5}$

Selanjutnya, pada abad ketiga ajaran tasawuf berkernbang ke arah pembahasan yang bersifat falsafi. Keadaan ini digambarkan oleh Aboebakar Atjeh sebagai herikut: "Lalu sampailah pada abad yang ketiga orang memhicarakan latihan ruhani, yang dapat membawa rnanusia kepada Tuhannya. Jika pada akhir abad kedua ajaran sufi merupakan kesuhudan (asketisisme), dalam abad ketiga ini orang sudah meningkat kepada wushul dan ittihâd dengan Tuhan (mistisisme). ${ }^{6}$

Menurut "Irfân "Abd al-Hamîd Fattâh, semenjak abad ketiga Hijriyah, yaitu dengan munculnya Abû Yazîd al-Bustâmî (m.261 H.), ajaran tasawuf ditandai dengan paham "persatuan" atau ittihâd Sebelum seorang sufi memasuki tahap persatuan dengan Tuhan (al-ittihâd) dia harus terlebih dahulu dapat menghilangkan eksistensi pribadinya melalui fanâ'. Menurut orang sufi, fanâ' berarti peniadaan kesadaran diri (al-fanâ' 'an al-nafs). Yang dimaksud dengan al-fana 'an al-nafs ialah hilangnya perasaan atau kesadaran seseorang

\footnotetext{
5 Abu al-Wafa al-Ghanimi Al-Taftazani, Madkhal Ila Al-Tasammuf al-Islami (Cairo: Dar alSawafah li al-Tiba wa al-Nasyr, 1979).

${ }^{6}$ Aboebakar Atjeh, Pengantar Sejarab Sufi \& Tasanuf (Solo: Ramadhani, 1984).

7 "Irfan" 'Abdb Al-Hamid Fattaf, Masy'ah Al-Falsafah Al-Sufiyah Wa Tatawmuruba (Beirut: Maktabah Al-Islami, 1973).
} 
terhadap wujud tubuh kasarnya dan alam sekitarnya ${ }^{8}$ Peniadaan diri (al-fanâ) ini dalam paham orang sufi senantiasa diiringi dengan baqa $\hat{a}^{\vartheta}$ Dalam sejarah perkembangan tasawuf, Abû Yazîd al-Bustâmî dipandang sebagai pembawa paham fana' dan baqa' ini; serta sekaligus sebagai pencetus paham Ittihâd. Dalam terminologi tasawuf, yang dimaksud dengan ittihâd kelihatannya ialah suatu tingkatan dimana seorang sufi telah merasa dirinya bersatu dengan Tuhan; suatu tingkatan dimana yang mencintai dan yang dicintai telah menjadi satu. ${ }^{10}$

Dalam perkembangan selanjutnya, paham Ittihâd ini mengambil bentuk bulûl. Hulûl menurut keterangan Abû Nasr a-Sarrâj al-Tûsî ialah suatu paham yang mengatakan bahwa Tuhan memilih tubuh-tubuh manusia tertentu untuk mengambil tempat di dalamnya setelah sifat kemanusian yang ada dalam tubuh itu dilenyapkan. ${ }^{11}$ Dengan gambaran singkat tersebut, dapat dilihat perbedaan yang menyolok antara ajaran tasawuf pada abad ketiga dan keempat ini dengan abad sebelumnya. Kalau pada abad sebelumnya tasawuf berkembang tanpa kendala, namun pada abad ketiga dan keempat dengan perkembangannya ke arah pembahasan secara falsafi yang ditandai dengan lahirnya paham ittihâd oleh Abû Yazîd al-Busthâmî dan hulûl oleh al-Hallâj, ia mendapat tantangan keras dari para ulama, terutama kalangan fuqahâ' dan mutakallimin yang tidak bisa rnenerima paham mereka tersebut.

Jadi menjelang lahirnya al-Ghazâlî telah terjadi pertentangan antara kaum sufi di satu pihak dengan fuqabâ' dan mutakallimin di pihak lain dan puncak ketegangan antara kaum sufi dengan fuqahấ adalah peristiwa tragis yang menimpa diri sufi, al-Hallâj. Dia harus menjalani eksekusi, yakni hukuman mati karena ajaran tasawufnya seperti disebutkan di atas. Menurut beberapa pengamat, di samping ajarannya di atas, tuduhan yang menyebabkan al-Hallâj harus dihukum bunuh: (1) Dia mempunyai hubungan dengan gerakan Qarâmitah, yaitu sekte Syi'ah yang mempunyai paham komunis, yang pernah menyerang Mekkah tahun 930 M., merampas Hajar Aswad yang dikembalikan oleh kaum Fatimi tahun 951 M., dan menentang pemerintahan Bani 'Abbas, mulai dari abad kesepuluh sampai abad kesebelas Masehi., (2) Keyakinan para

\footnotetext{
8 'Abd al-Karim Al-Quasyairi, Al-Risalah al-Quasyairiyah (Cairo: Dar al-Kutub al-'Arabiyah alKubra, n.d.).

${ }^{9}$ Reynold Nicholson, Studies in Islamic Mysticism (London: Cambridge University Press, 1921).

${ }^{10}$ Harun Nasution, Falsafah \& Mistisisme Dalam Islam (Jakarta: Bulan Bintang, 1973).

${ }^{11}$ Abu Nasr al-Surraj al-Tusi, Al-Luma' (Cairo: Dar al-Kutub al-Hadisah, 1960).
} 
pengikutnya bahwa dia mempunyai sifat Ketuhanan, (3) Ucapannya: Anâ alHaqq (Akulah yang Maha Benar), dan (4) Ibadah haji tidak wajib. ${ }^{12}$

\section{Usaha Imam al-Ghazali dalam Menyelamatkan Tasawuf}

Ibyâ' Ulîm al-Dîn adalah suatu karya yang nyata dibidang tasawuf yang dikarang oleh AL-Ghalazi. Menurut A.J. Arberry, Ibyâ' 'Ulûm al-Din merupakan kitab al-Ghazâlî yang terbesar mengenai keagamaan yang digubah oleh seorang muslim, yang secara gamblang mengungkapkan kaitan antara teologi sunni dan syariat agama. ${ }^{13}$ Al-Ghazali berupaya melakukan sintese pengamalan ajaran agama yang dilakukan sesuai dengan terpenuhinya rukun dengan terisinya nilai dari pelaksanaan ajaran agama itu. Sebagai contoh, dalam kitab Ibya' tentang pelaksanaan puasa ia membagi puasa ke dalam dua penilaian, pertama rukunrukun puasa (arkan al-shawm) dan yang kedua nilai-nilai puasa (asrar al-shawm). ${ }^{14}$ Demikian usaha al-Ghazâlî dalam menyelamatkan ajaran tasawuf yang sangat menentukan nasibnya di kemudian hari. Di sinilah, barangkali, terletak kebesaran al-Ghazâlî dalam mencari sintese yang mantap antara unsur-unsur yang dipandang bertentangan dalam khazanah intelektual Islam.

Dengan demikian dapat dikatakan bahwa jasa terbesar al-Ghazâlî terhadap perkembangan tasawuf adalah usahanya mengintegrasikan ajaran tasawuf, sebagai salah-satu aspek dari ajaran Islam, dengan aspek-aspek ajaran Islam yang lain, fiqh dan teologi. Ajaran tasawuf, yang dalam perkembangannya hingga saat menjelang kehadiran al-Ghazâlî, seperti digambarkan di atas, sudah dianggap tidak "halal" lagi bagi kaum muslimin. Di sini dapat dilihat bagaimana kemampuan al-Ghazâlî memberikan sintese antara ajaran tasawuf dengan fiqh dan teologi yang pada masanya dipandang bertentangan antara yang satu dengan yang lainnya.

Dalam khazanah kepustakaan Barat, al-Ghazâlî biasa ditempatkan sejajar dengan St.Agustinus (354-430 M.), filosof Kristen yang mengarang buku The City of God. Bedanya, Agustinus tetap lengket dengan filsafat sampai akhir hayatnya, sementara al-Ghazâlî menempuh jalan tasawuf bagi pencarian kebenaran. ${ }^{15}$ Orientalis H.A.R Gibb disamping mensejajarkan al-Ghazâlî

\footnotetext{
${ }^{12}$ Nasution, Falsafah \& Mistisisme Dalam Islam; Nicholson, Studies in Islamic Mysticism.

13 A.J Arberry, Sufism: An Account of The Mystics of Islam (London: YNwin Paperbacks, 1973).

${ }^{14}$ Al-Gazali AL-Ghazali, Ibya 'Ulum al-Din (Beirut: Dar al-Fikr, n.d.).

15 Arthur Hyman and James J Wals, Philosophy in The Middle Age (Indianapolis: Hackett Publishing Company, n.d.).
} 
dengan St. Agustinus, juga menempatkannya setaraf dengan Martin Luther, pernbaharu agama Kristen di Eropa pada permulaan abad ke-16 Masehi. ${ }^{16}$

Fazlur Rahman melihat bahwa gerakan pembaharuan yang bermaksud mengintegrasikan kesadaran tasawuf dengan syariat telah dimulai pada pertengahan kedua abad ketiga Hijriyah/kesembilan Masehi dengan kegiatan tokoh-tokoh seperti al-Kharrâs dan al-Junaid. Namun gerakan ini mencapai puncaknya dalam tokoh monumental al-Ghazâlî, yang terbukti kemudian adalah tiang utama gerakan tersebut. Tokoh terbesar Islam abad pertengahan ini terbukti menjadi tokoh yang menentukan terhadap perkembangan Islam selanjutnya, Iebih banyak melalui apa yang diajarkannya berdasarkan pengalaman pribadi daripada apa yang dipikirkannya. ${ }^{17}$

Selanjutnya Rahman mengatakan bahwa pengaruh al-Ghazâlî dalam Islam adalah tak terkirakan besarnya. Dia tidak hanya membangun kembali Islam sunni dengan menjadikan tasawuf sebagai bagian integral daripadanya, tapi dia juga merupakan pembaharu tasawuf yang besar, yang membersihkannya dari unsur-unsur yang tak islamis dan mengabdikannya kepada paham Islam sunni. Dengan demikian ia merupakan tahap atau langkah akhir dari suatu sejarah perkembangan yang panjang. Melalui pengaruhnya, tasawuf memperoleh restu dan konsensus masyarakat Islam. Islam memperoleh daya hidup dan daya tarik yang baru yang menyebabkan tersebar ke daerah-daerah yang luas di Afrika, Asia Tengah dan India. Sejak masa itu dan seterusnya, seringkali seorang teolog besar adalah juga seorang sufi besar pula. ${ }^{18}$

Ibrâhîm Madkûr ketika membicarakan posisi al-Ghazâlî dalam percaturan tasawuf yang berbenturan dengan teologi dan fiqh akibat perkembangannya ke arah mistik ("suatu ajaran tentang adanya hubungan dan kemungkinan persatuan jiwa manusia dengan Tuhan"19 yakni paham Itthiâd dan Hulûl, memandang al-Ghazâlî sebagai seorang yang memikul tugas berat untuk membela Ahlu Sunnah dalam segala aspeknya, memerangi ahli bid'ah, bagaimanapun kelompok dan kepercayaan mereka, baik para teolog, kebatinan maupun sufi; dan sekaligus al-Ghazâlî adalah peletak prinsip dan kaidah-kaidah

\footnotetext{
${ }^{16}$ H.A.R Gibb, Mohammedanism (New York: Oxford University Press, 1969).

17 Fazlur Rahman, Islam \& Modernity: Transformation of an Intelevtual Tradition (Chicago \& London: The University of Chicago Press, 1984).

${ }^{18}$ Rahman.

${ }^{19}$ James Hastings, Encyclopedia of Religion and Ethnics, vol. IX (New York: Charles Scrobmer's Son, n.d.).
} 
"tasawuf sunni". Al-Ghazâlî telah menjelaskan metode dan sarana-sarananya di dalam kitabnya Ihyâ' 'Ulûm al-Dîn yang segera menjadi pegangan orang-orang sufi sesudahnya. ${ }^{20}$ Sebagaimana Ibrahîm Madkûr, Abû al-Wafầ al-Taftâdzânî mengemukan pernyataan serupa tentang peranan al-Ghazâlî dalam sejarah penyelamatan tasawuf sunni. ${ }^{21}$

H.A.R. Gibb mengatakan bahwa al-Ghazâlî, sebagai seorang teolog Asy'ariyah, telah mampu membangun kembali teologi di atas dasar pengalaman tasawuf pribadi. Namun hal ini jangan diartikan bahwa dengan mengikuti jalan sufi, ia menolak teologinya yang terdahulu, tetapi keyakinan-keyakinan dari pengalaman pribadi itu memungkinkannya, dengan keberanian dan keyakinan besar, mengkombinasikan sistem-sistem pemikiran teologi, filsafat dan tasawuf yang sampai sekarang masih kelihatan terpisah-pisah dan saling bertentangan. ${ }^{22}$

Di dalam bukunya Modern Trends in Islam, Gibb mengungkapkan hal yang sama tentang peranan al-Ghazâlî dalam sejarah perkembangan tasawuf. Namun lebih jauh dikatakan bahwa usaha al-Ghazâlî yang cukup berharga bagi kelangsungan hidup tasawuf sebagai landasan teologi sunni tidak berlangsung lama, karena beberapa tokoh sufi terjerumus lebih dalam lagi, yakni masuk ke dalam lingkungan panteisme. ${ }^{23}$

Secara tegas dapat dikatakan bahwa dampak dari usaha al-Ghazâlî itu hanya mampu bertahan selama kurang lebih satu abad, karena pada abad keenam Hijriyah/kedua belas Masehi dan seterusnya paham "kesatuan wujud" atau panteisme (dengan meminjam istilah Gibb) muncul kembali dengan uraiannya yang lebih sistematis dan sempurna. Kehadiran tokoh-tokoh sufi seperti al-Suhrawardî al-Maqtûl (w.578 H.), Ibn 'Arabî (w.638 H.), Ibnu Sab'în (w.669 H-), Ibnu al-Fârid (w.632 K,), Jalâluddin al-Rûmî (w.672 H.) dan 'Abd al-Karim al-Jili $(w .805 \mathrm{H})$ menandakan lahirnya babak baru dari paham "kesatuan wujud" dalam perjalanan panjang tasawuf atau mistisisme dalam Islam.

Menurut Duncan B. Macdonald, salah satu pengaruh terbesar alGhazâlî terhadap dunia Islam ialah usahanya meyakinkan kembali keberadaan tasawuf sebagai salah satu aspek dari ajaran Islam. Lengkapnya, secara ringkas - demikian Macdonald - dapat dirumuskan ada empat usaha dan pengaruh al-Ghazâlî terhadap perkembangan Islam sesudahnya; dan dari keempat

\footnotetext{
${ }^{20}$ Ibrahim Madkur, Fi Al-Falsafah al-Islamiyah I (Cairo: Dar al-Fikri al-'Arabi, n.d.).

${ }^{21}$ Madkur.

22 Gibb, Mohammedanism.

${ }^{23}$ H.A.R Gibb, Modern Trends in Islam (New York: Octagon Books, 1978).
} 
tersebut ada dua hal yang paling berpengaruh, yaitu: Pertama, ia membawa orang kembali dari pemikiran skolastik terhadap dogma teologis kepada hubungan yang hidup dan langsung dengan studi dan penafsiran al-Qur'an dan al-Sunnah. Kedua, adalah karena pengaruhnya, tasawuf memperoleh posisi yang kuat dan meyakinkan di dunia Islam. ${ }^{24}$

Sekarang dapat dikatakan bahwa sebenarnya al-Ghazâlî berusaha mengembalikan tasawuf kepada keadaan-nya pada abad pertama dan kedua yang dipandang masih murni, yang sesuai dengan ajaran al-Qur'an dan alSunnah. Dan dia mengukuhkan kembali bahwa tasawuf, sebagai kehidupan agama yang emosional, adalah salah satu ajaran yang penting bagi setiap muslim, sebagaimana ajaran-ajaran Islam yang lain.

Orientalis W. Montgomery Watt juga menilai bahwa salah satu sukses besar al-Ghazâlî, hingga dia dipandang sebagai seorang muslim terbesar kedua setelah Muhammad saw, adalah upayanya merukunkan pertentangan dan benturan antara teologi dengan tasawuf — sebagaimana dikemukakan di atas - kendati keduanya tetap berjalan di atas relnya masing-masing. ${ }^{25}$ Penilaian serupa juga pernah disampaikan Watt dalam bukunya The Majesty That was Islam, Islamic World 661-1100. ${ }^{26}$

Al-Ghazâlî yang sering dibandingkan atau disejajarkan dengan St. Augustinus - sebagaimana telah disebutkan di atas —, dampak konversinya terhadap Islam, kata A.J. Arberry, sama besarnya dengan dampak konversinya St.Agustinus terhadap agama Kristen. Dampak penting-nya terhadap Islam, secara ringkas dapat dicirikan lewat ungkapan, bahwa al-Ghazâlî berhasil meyakinkan sikap mistik atau introspektif dalam suatu wadah ajaran Islam yang sah (benar) berdampingan dengan legalisme para fuqahâ' dan intelektualisme para mutkallimin. ${ }^{27}$ Pendapat serupa juga dikemukakan oleh Reynold A. Nicholson dalam bukunya The Mystics of Islam. ${ }^{28}$

Dapat dikatakan pula, bahwa keberhasilan al-Ghazâlî dalam menyelamatkan aspek batini atau esoterik Islam, yaitu tasawuf, dengan mengintegrasikannya dengan aspek lahiri atau eksoterik, yaitu fiqh dan teologi,

\footnotetext{
${ }^{24}$ Duncan B Macdonald, Development Od Muslim Theology, Juruprudence and Constitutional Theory (New York: Charles Scrobmer's Son, 1992).

${ }^{25}$ W. Montgomery Watt, The Faith and Practice of AL-Ghazali (London: George Allen and Unwin Ltd, 1955).

${ }^{26}$ W. Montgomery Watt, The Majesty That Was Islam: The Islamic World 661-1100 (London: Sidgwick \& Jackson, 1974).

27 Arberry, Sufism: An Account of The Mystics of Islam.

${ }^{28}$ Nicholson, Studies in Islamic Mysticism.
} 
dapat dilihat pada pengaruhnya yang begitu luar biasa dalam masyarakat Islam. Dia sering dikatakan dan dipuji sebagai seorang pemimpin terbesar dalam Islam setelah Muhammad saw. Sebagaimana dikatakan Watt di atas, al-Ghazâlî, baik di Barat maupun di Timur, kadang-kadang dipuji sebagai seorang muslim terbesar setelah Muhammad; dan pujian tersebut bukanlah sesuatu yang tak berhak dia menerimanya. Dan dalam hubungan pujian umat muslim kepada alGhazâlî ini pula, maka kitabnya yang sangat terkenal Ihyâ' 'Ulûm al-Dîn dipandang oleh Imâm al-Nawawi, seperti dikutip 'Abd al-Halìm Mahmûd "hampir saja seperti al-Qur'an." (كاد الأحياء يكون قر انا).

Samuel M. Zwemer mengatakan bahwa ada empat orang yang paling besar jasanya dalam Islam, yaitu Nabi Muhammad sendiri, Imâm Bukhâri sebagai pengumpul hadis yang paling masyhur. Imâm al-asy'arî sebagai teolog terbesar dan penentang rasionalisme, dan Imâm al-Ghazâlî sebagai seorang "reformer" dan sufi. Nama yang disebutkan paling akhir ini telah meninggalkan pengaruh yang begitu luas dalam sejarah Islam dibandingkan dengan siapa pun setelah Muhammad. ${ }^{29}$ Boleh jadi, karena jasa dan pengaruh-nya yang begitu besar itulah, maka al-Sayuti - kutip Zwemer - dan banyak kaum muslimin — kata Nicholson - mengatakan: "Seandainya setelah Nabi Muhammad ada seorang nabi, maka al-Ghazâlî lah nabinya." ${ }^{30}$ Dan barangkali karena kemasyhurannya ini pula maka. Annemarie Schimmel mengatakan: "Tak ada pemikir zaman pertengahan Islam yang bisa menarik minat para cendekiawan Barat lebih dari al-Ghazâlî. Karya-karyanya telah diterjemahkan ke dalam sejumlah besar bahasa Barat." 31

Keberhasilan al-Ghazâlî menyelematkan tasawuf dari konfrontasinya dengan teologi dan figh, seperti diakui oleh para pakar di atas, boleh jadi didukung oleh kemampuan keilmuan yang dimilikinya serta teknik pendekatan yang dia gunakan. Al-Ghazâlî diakui sebagai seorang muslim yang mempunyai keahlian dalam berbagai bidang ilmu pengetahuan, sebagaimana dapat dilihat dalam karya-karyanya yang mencakup dalam berbagai disiplin. ${ }^{32}$

Suatu sikap yang patut dicontoh, bahwa ketika al-Ghazâlî ingin menilai suatu paham atau ajaran dari suatu mazhab atau golongan, terlebih dahulu dia

\footnotetext{
${ }^{29}$ Samuel . M Zwemer, A Moslem Seeker after God (New York: Fleming H.Revell Company, 1920).

30 Zwemer; Nicholson, Studies in Islamic Mysticism.

31 Annemarie Schimmel, Demensi Mistik Dalam Islam (Penerjemah Sapardi Djoko Damono, Dkk) (Jakarta: Pustaka Firdaus, 1986).

32 Arberry, Sufism: An Account of The Mystics of Islam.
} 
mengkaji apa yang dia teliti itu sedalam-dalamnya. Dengan demikian, kesimpulan yang dia berikan itu benar-benar berdasar fakta dan pengkajian yang matang dan mendalam. Sebagai contoh, ketika al-Ghazâlî mengadakan pengkajian terhadap Ilmu Kalam, dia mengatakan: "Aku mulai dengan mengkaji Ilmu Kalam sehingga aku memperoleh pengetahuan dan memahaminya. Aku pun telah menelaah kitab-kitab dari para ahlinya dan aku juga telah menyusunnya menurut susunan yang kuinginkan." ${ }^{33}$ Dan ketika mengkaji filsafat, dia mengatakan: "Setelah selesai mempelajari Ilmu Kalam, segera aku menyelidiki filsafat. Aku berkeyakinan bahwa seseorang tidak akan dapat mengetahui kesalahan suatu ajaran sebelum ia mempeiajari sedalamdalamnya seluk beluk ajaran itu. Bahkan harus lebih dari itu, sehingga ia mungkin dapat melihat kesalahan ajaran itu, jika memang ada." ${ }^{34}$ Dengan demikian dapat dikatakan bahwa telah menjadi kebiasaan bagi al-Ghazâlî untuk mempelajari tata-cara dari masing-masing kelompok yang dia teliti guna mendapatkan suatu pandangan, kemudian merumuskan pendapatnya, lalu menilai dan mengkritik ajaran-ajaran mereka. Kebiasaan ini dianggapnya sebagai hal yang penting untuk rnenyelamatkan kebenaran dari penilaian lewat perdebatan kosong.

Suatu hal yang perlu diingat bahwa keberhasilan al-Ghazâlî dalam meyakinkan kembali keberadaan tasawuf adalah karena sikapnya memilih tasawuf sebagai jalan hidup di akhir hayatnya yang dia putuskan setelah melewati perjuangan intelektual dan spiritual yang cukup lama dan menegangkan. Dengan cara begitu, tentulah dampaknya akan lebih dapat meyakinkan orang terhadap kebenaran sikap yang dia ambil dan ajaran yang dia sampaikan.

Selanjutnya, suatu hal yang perlu diingat pula, bahwa keberhasilan alGhazâlî itu juga didukung oleh kemampuannya membaca keadaan umat pada masanya. Dia menggunakan bahasa, ungkapan dan penjelasan yang lebih komunikatif dan manusiawi. Namun konsekuensi dari caranya inilah barangkali yang mengakibatkan adanya pernyataan-pernyataan al-Ghazâlî yang tidak konsisten - paling tidak hal itu tampak dipermukaan. Sebagai contoh, di dalam kitabnya al-Munqidz, al-Ghazâlî menolak adanya paham Ittihâd dan Hulûl, yang dikatakannya sebagai khayalan sekelompok orang. ${ }^{35}$ Dengan sikapnya seperti itu, belakangan ini banyak para pengamat cenderung memegangi

\footnotetext{
${ }^{33}$ AL-Ghazali, Al-Minqiz Min Al-Dalal.

${ }^{34}$ AL-Ghazali.

${ }^{35}$ AL-Ghazali.
} 
pendapatnya di dalam kitab Misykât al-Anwâr daripada apa yang dia nyatakan dalam kitab Ibyâ' 'Ulûm al-Din. ${ }^{36}$ Di tambah lagi kitab Misykât al-Anwâr merupakan karya terakhir yang ditulis al-Ghazâlî, karena itu ia menggambarkan pendapat terakhir yang dipegangi al-Ghazâlî. Jika ditinjau lebih jauh, kehadiran kembali paham "kesatuan wujud" pada abad keenam Hijriyah/keduabelas Masehi setelah wafatnya al-Ghazâlî, yang pernah muncul pada abad ketiga dan empat Hijriyah/kesembilan dan sepuluh Masehi seperti dikemukakan di atas, secara tidak langsung telah diberi peluang oleh kitab al-Ghazâlî yang terakhir ini. Demikian penilaian yang dikemukakan oleh Annemarie Schimmel. ${ }^{37}$

Dengan demikian perlu diingat bahwa di balik kehebatannya, al-Ghazâlî adalah seorang manusia biasa yang dalam beberapa hal juga menunjukkan kelemahannya. Salah satu kelemahan itu ialah yang berkenaan dengan sikapnya terhadap tasawuf ini — sebagaimana diterangkan di atas. Mungkin karena dia memiliki semangat intelektual yang tinggi, yang mendorongnya untuk mengkaji dan menguji apa saja yang ada pada lingkungannya, al-Ghazâlî sering memperlihatkan sikap-sikap yang tidak konsisten. Banyak pengkaji yang melihat ketidak konsistenan al-Ghazâlî sebagai penunjuk ketinggian intelektualnya yang selalu mencari kebenaran dan terus-menerus ingin tahu itu, yang sekaligus menggambarkan proses perkembangan intelektual dan spiritualnya. Tegasnya hal ini justru menunjukkan kehebatannya dalam menampilkan ajaran tasawuf hingga ia dapat diterima oleh segala lapisan sesuai dengan tingkat kemampuan orang yang menerimanya.

Al-Ghazâlî yang memakai bahasa filsafat dan pola argumentasi yang bersifat sufistik telah menyebabkan sementara penulis menuduhnya sebagai "yang tersesat". Qadi Abû "Abdillah Muhammad ibn Hamdin dari Cordova telah mengeluarkan fatwa yang menentang seluruh karya al-Ghazâlî. Akibatnya, karangannya, termasuk Ihya', dibakar dan dibinasakan di seluruh Spanyol. Memiliki karya-karyanya diharamkan, bahkan pemiliknya dapat diancam hukuman mati. Situasi serupa juga dapat dijumpai di Afrika Utara dimana karya-karyanya telah dihancurkan

Menurut Fazlur Rahman, dikalangan Sunni sendiri - dimana alGhazâlî dipandang sebagai salah seorang tokohnya - terdapat kelompokkelompok yang tidak menerima sintese yang dilakukan al-Ghazâlî. Satu di antaranya adalah kelompok Ahl al-Hadis, yaitu para tradisionalis yang memandang sintese al-Ghazâlî sebagai sesuatu yang asing bagi Islam, dan

\footnotetext{
${ }^{36}$ Schimmel, Demensi Mistik Dalam Islam (Penerjemah Sapardi Djoko Damono, Dkk).

${ }^{37}$ Nicholson, Studies in Islamic Mysticism.
} 
karenanya patut dicurigai. Al-Ghazâlî juga diserang karena dipandang telah menggunakan hadis-hadis yang lemah dan bahkan palsu untuk menunjang penafsiran-penafsiran sufistiknya. Kelompok kedua, yaitu para mitakallimin yang lebih intelektualis, tidak bisa menerima seruan al-Ghazâlî karena tidak mampu memuaskan tuntutan intelektualisme secara formal. ${ }^{38}$

Akan tetapi bagaimanapun penilaian orang kepadanya, namun yang lebih jelas al-Ghazâlî adalah seorang intelektualis besar, seorang pemikir yang tidak saja kritis dan mendalam, tapi juga sangat subur dan produktif dengan karya-karya agung dan monumental yang mampu bertahan hingga saat ini. Dia dipandang sebagai salah seorang yang paling menentukan jalannya sejarah Islam dan umat muslim karena, sebagaimana diterangkan di atas, dia berhasil menciptakan sintese keagamaan yang tiada taranya dalam sejarah pemikiran Islam, termasuk keberhasilannya dalam mengintegrasikan ajaran tasawuf dengan ajaran-ajaran Islam lainnya hingga menjadi ajaran yang utuh. Dengan demikian, tasawuf, yang sebelumnya dipandang telah tersesat karena olah "oknum minoritas yang tidak bertanggungjawab", dapat diterima kembali oleh mayoritas kaum muslim sebagai ajaran yang tidak hanya dapat diterima, namun juga sangat dibutuhkan oleh setiap orang muslim untuk menghadapi segala problema hidup dan kehidupan.

\section{Simpulan}

Sebagai pengamalan, sesungguhnya ajaran tasawuf telah ada sejak abad pertama Hijrah sebagaimana yang dipraktekkan oleh Rasulullah saw dan para sahabat beliau seperti tekun beribadah, bersifat sabar, syukur, ikhlas dan sifat-sifat terpuji lainnya. Sebagai istilah dan ilmu, tasawuf baru muncul pada abad kedua Hijrah. Pada abad pertama dan kedua Hijrah, ajaran tasawuf masih berada dalam lingkaran ajaran tasawuf akhlaki dan amali seperti yang dipraktekkan oleh Nabi saw dan para sahabat. Namun pada abad ketiga dan keempat ajaran tasawuf diwarnai oleh memikiran falsafi atau tasawuf falsafi seperti paham Ittihad yang dibawa oleh Abu Yazid al-Busthami dan paham Hulul yang dibawa oleh Abu Manshur al-Hallaj. Kedua ajaran ini ditentang oleh para ulama (teolog dan fuqaha) karena dipandang telah sesat, yang akibatnya tasawuf mengalami nasib terpuruk.

Dalam keadaan tasawuf yang sedemikian itu, Imam al-Ghazali tampil untuk menyelamatkaannya karena menurutnya tasawuf adalah bagian dari ajaran Islam yang tak terpisahkan dari ajaran-ajaran Islam lainnya. Al-Ghazali

${ }^{38}$ Rahman, Islam \& Modernity : Transformation of an Intelevtual Tradition. 
dipandang sebagai salah seorang yang paling menentukan jalannya sejarah Islam dan umat muslim karena, sebagaimana diterangkan di atas, dia berhasil menciptakan sintese keagamaan yang tiada taranya dalam sejarah pemikiran Islam, termasuk keberhasilannya dalam mengintegrasikan ajaran tasawuf dengan ajaran-ajaran Islam lainnya hingga menjadi ajaran yang utuh. Dengan demikian, tasawuf, yang sebelumnya dipandang telah tersesat jalan, dapat diterima kembali oleh mayoritas kaum muslim sebagai ajaran yang tidak hanya dapat diterima, namun juga sangat dibutuhkan oleh setiap orang muslim untuk menghadapi segala problema hidup dan kehidupan, baik kehidupan beragama maupun bermasyarakat.

\section{Daftar Pustaka}

AL-Ghazali, Al-Gazali. Al-Minqiz Min Al-Dalal. Turkey: Hakikat Kitabevi, 1981.

- Ihya 'Ulum al-Din. Beirut: Dar al-Fikr, n.d.

Al-Quasyairi, 'Abd al-Karim. Al-Risalah al-Quasyairiyah. Cairo: Dar al-Kutub al'Arabiyah al-Kubra, n.d.

Al-Taftazani, Abu al-Wafa al-Ghanimi. Madkhal Ila Al-Tasawnuf al-Islami. Cairo: Dar al-Sawafah li al-Tiba wa al-Nasyr, 1979.

Arberry, A.J. Sufism: An Account of The Mystics of Islam. London: YNwin Paperbacks, 1973.

Atjeh, Aboebakar. Pengantar Sejarah Sufi \& Tasawnf. Solo: Ramadhani, 1984.

Fattaf, "Irfan" 'Abdb Al-Hamid. Masy'ab Al-Falsafab Al-Sufiyah Wa Tatawwuruba. Beirut: Maktabah Al-Islami, 1973.

Gibb, H.A.R. Modern Trends in Islam. New York: Octagon Books, 1978.

-. Mohammedanism. New York: Oxford University Press, 1969.

Hastings, James. Encyclopedia of Religion and Ethnics. Vol. IX. New York: Charles Scrobmer's Son, n.d.

Hyman, Arthur, and James J Wals. Philosophy in The Middle Age. Indianapolis: Hackett Publishing Company, n.d.

Macdonald, Duncan B. Development Od Muslim Theology, Juruprudence and Constitutional Theory. New York: Charles Scrobmer's Son, 1992.

Madkur, Ibrahim. Fi Al-Falsajah al-Islamiyah I. Cairo: Dar al-Fikri al-'Arabi, n.d.

Nasution, Harun. Falsafah \& Mistisisme Dalam Islam. Jakarta: Bulan Bintang, 1973.

Nicholson, Reynold. Studies in Islamic Mysticism. London: Cambridge University Press, 1921. 
Rahman, Fazlur. Islam \& Modernity : Transformation of an Intelevtual Tradition. Chicago \& London: The University of Chicago Press, 1984.

Schimmel, Annemarie. Demensi Mistik Dalam Islam (Penerjemah Sapardi Djoko Damono, Dkk). Jakarta: Pustaka Firdaus, 1986.

Tusi, Abu Nasr al-Surraj al-. Al-Luma'. Cairo: Dar al-Kutub al-Hadisah, 1960. Watt, W. Montgomery. The Faith and Practice of AL-Gharali. London: George Allen and Unwin Ltd, 1955.

- The Majesty That Was Islam: The Islamic World 661-1100. London: Sidgwick \& Jackson, 1974.

Zwemer, Samuel . M. A Moslem Seeker after God. New York: Fleming H.Revell Company, 1920. 